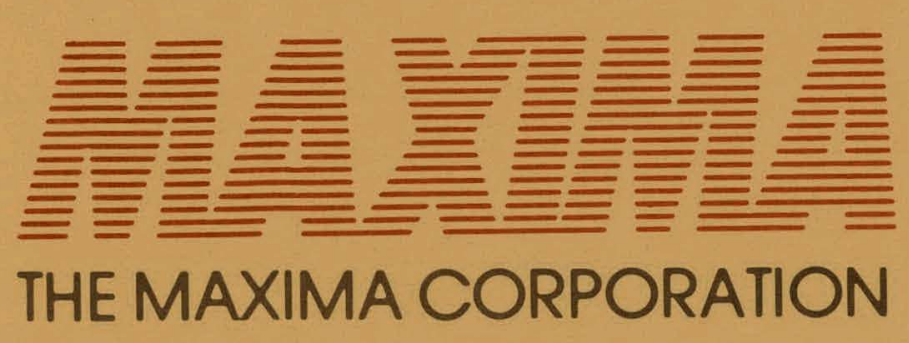

\title{
Review of the Proposed Quarterly Coal Review
}

Prepared by

The MAXIMA Corporation
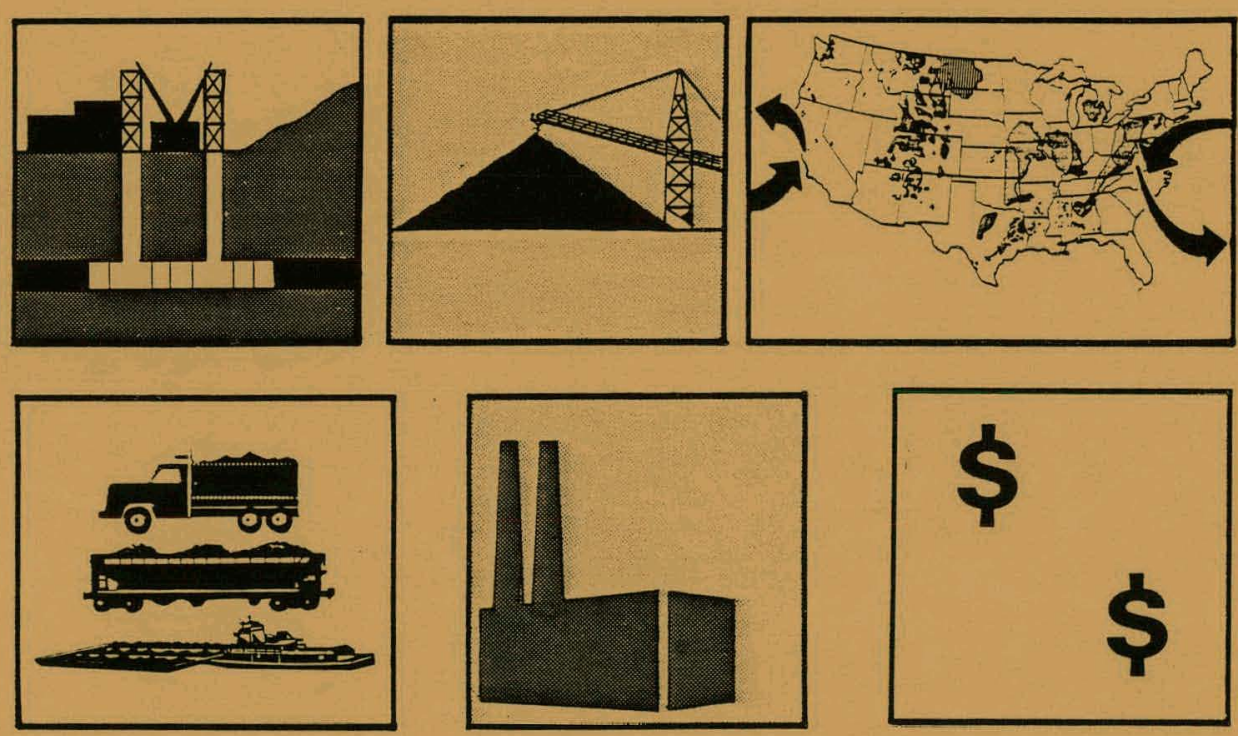


\section{DISCLAIMER}

This report was prepared as an account of work sponsored by an agency of the United States Government. Neither the United States Government nor any agency Thereof, nor any of their employees, makes any warranty, express or implied, or assumes any legal liability or responsibility for the accuracy, completeness, or usefulness of any information, apparatus, product, or process disclosed, or represents that its use would not infringe privately owned rights. Reference herein to any specific commercial product, process, or service by trade name, trademark, manufacturer, or otherwise does not necessarily constitute or imply its endorsement, recommendation, or favoring by the United States Government or any agency thereof. The views and opinions of authors expressed herein do not necessarily state or reflect those of the United States Government or any agency thereof. 


\section{DISCLAIMER}

Portions of this document may be illegible in electronic image products. Images are produced from the best available original document. 


\title{
Review of the Proposed Quarterly Coal Review
}

\author{
Submitted to \\ The Office of Energy Data Operations \\ Energy Information Administration \\ Under Contract No. DE-AC01-80EI-10313
}

Prepared by

The MAXIMA Corporation

Suite 900N

Bethesda, Maryland 20014

April 1981

This book was prepared as an a DIMER This book was prepared as an account of work sponsoned by an agency of the United States Governmen. warranty, express or implied, or assumas any legal liability or al their employees, makes any completeness. a usefulness of any inforrstation, apparalus, oroduct. or process disclosed or represents tnat its use would not intringe privately owned rights. Reierence herein to any soecitic commercial product. process, or sevvice by trade name, lradenark, manulacturer, or otherwise, does not necessarily constivie or imply its endorsement, recommendation, or lavoring by the United necessarily state or reflect those of the Uniled sroes ${ }^{2}$ 


\section{Executive Summary}

This "Review of the Proposed Quarterly Coal Review" is the second of two reports that contain analyses and recommendations regarding a new Energy Information Administration (EIA) summary coal publication entitled Quarterly Coal Review (QCR). The first report concentrated on substantive publication issues such as user needs, data availability and general publication content.

This second report includes more specific analyses of publication content and data presentation formats. There are two sections in this report: Chapter, Table and Graph Formats; and Detailed Analysis of Chapter Content.

The report contains options and recommendations within each of the sections. The major findings contained in this report are summarized below:

- Data within the chapters should conform to the standard of aggregate to disaggregate ordering .

- A syntactic structure for titles should be adopted.

- Totals data should be placed at the top and/or left of each table.

- A comprehensive Scope of Publication page or section that includes data source information will eliminate lengthy sources footnotes.

- Data presented in the executive summary should provide a brief synopsis of the content of the publication and should include data that facilitates supply and disposition equations.

- The domestic shipments chapter should include the following data in a concise format (depending on the options selected):

- the amount and origin of coal shipments

- the state of destination

- the method of transportation

- the destination by consumption sectors of coal shipments 
- A receipts chapter should be established that includes all available coal cost and quality data.

In the following sections of this report, we will expand on the rationale behind each recommendation and provide examples and options. 


\section{Introduction}

This "Review of the Proposed Quarterly Coal Review" is the second of two reports and contains the results of our analysis of issues regarding the publication of a new summary publication, the Quarterly Coal Review. The first report on the QCR was submitted to the Office of Energy Data Operations (OEDO) in January, 1981 and included results of our analysis and recommendations concerning data availability and content organization.

This report concentrates on data presentation and publication format for the proposed QCR. Comprised of two sections, the report addresses chapter and table formats and presents a detailed analysis of chapter content.

The first section of this report, Chapter, Table and Graph Formats, consists of findings and recommendations on the ordering, titling, endnotes and cosmetics of the tables proposed for for the QCR. The next section, Detailed Analysis of Chapter Content, is the result of a more in-depth analysis of chapters in the QCR. 


\section{Chapter, Table and Graph Formats}

This section contains findings and recommendations concerning chapter, table and graph formatting.

\section{Chapter Format}

The following paragraphs consist of recommendations for the presentation of data within the chapters of the proposed $Q C R$.

\section{Chapter Ordering}

The proposed QCR will contain seven chapters:

- Production

- Stocks

- Imports

- Exports

- Domestic Shipments

- Receipts

- Consumption

Although these chapters may be ordered in a number of ways, virtually all of the data within each of these chapters will be presented on tables and graphs. Therefore, it is important to organize the data within each chapter in a way that is logical to the reader and that will facilitate a better understanding of the data contained in the publication. Furthermore, once a convention for organizing the data presentations in a chapter has been established, the convention should be retained for each chapter in the publication. 
The best way to organize data presentations on a particular subject, for example, within a chapter, is to progress from the most general data presentation to the most specific. In some instances it may be better to begin with the most detailed breakdowns of data and move toward larger aggregation. However, in a summary publication of this sort, the reader is likely to use the more general tables and graphs most frequently, and the placement of general or summary totals tables first can help the reader understand the more specific data that follow. As an example, the data tables to be included in the consumption section of the proposed QCR are presented using the aggregate to disaggregate convention for chapter organization:

- U.S. Consumption of Coal

- Consumption of Coal by State

- Consumption of Coal at Electric Utilities by State

- Consumption of Coal at Coke Plants by State

- Consumption of Coal at Other Industrial by State

- Consunption of Coal at Residential/Commerofal by Stale

Exhibit 1, "Summary Table and Graph," is an example of the type of table that should be placed first in the chapters.

\section{$\underline{\text { Running Heads }}$}

The QCR will consist primarily of tables and graphs. To orient the reader and ease referencing, we recommend that running heads be placed at the top of each page. All exhibits included in this report contain examples of running heads. 


\section{Production}

Table . Production of Coal, U.S. Total, January - March 1981,

October - December 1980, January - March 1980

(Thousand Short Tons)

\begin{tabular}{|c|c|c|c|c|c|}
\hline \multirow{2}{*}{ Area } & \multirow{2}{*}{$\begin{array}{c}\text { January - March } \\
1881\end{array}$} & \multirow{2}{*}{$\begin{array}{c}\text { October - December } \\
1980\end{array}$} & \multirow{2}{*}{$\begin{array}{c}\text { January- Mareh } \\
1880 \\
-\end{array}$} & \multicolumn{2}{|c|}{ Yoar to Date } \\
\hline & & & & 1881 & 1880 \\
\hline U.S. Total & $x$ & $x$ & $x$ & $x$ & $x$ \\
\hline
\end{tabular}

Sources - EIA 6 and State Agencies.

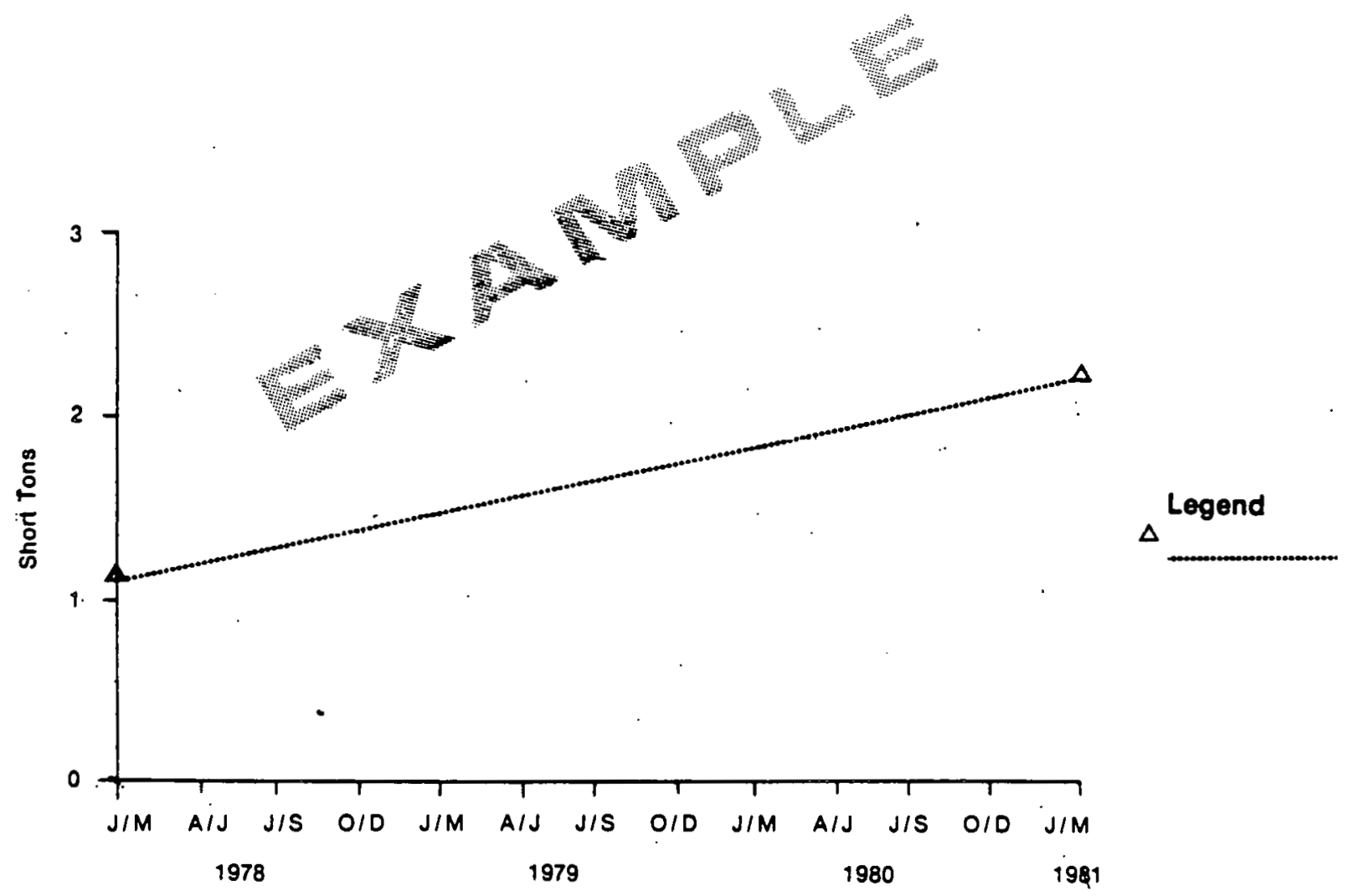

Sources E EIA 6 and State Agencies.

Figure . Production of Coal, U.S. Total by Calendar Quarter, 1978 - 1981

Exhibit 1. Summary Table and Graph 


\section{Table Format}

According to the Energy Information Administration Publications Manual, Volume 1, a formal table consists of five parts:

- Main heading, including reference number, title and headnote

- Boxhead, including the spanners, subspanners and subhead

- Stub or line captions

- Field, including field spanners and cells

- Enduutes, Including footnotes, notes and source references

An example of a formal table according to these standards, is illustrated in Exhibit 2. All of the components should combine "to arrange and present the data so that the meaning and style are readily grasped" (EIA Publications Manual, Volume 1). We have reveiwed each of the five cable components and recommend alternatives that satisfy these criteria.

Main Heading

The title is the most important element in the main heading and should clearly identify the data within the table. Each table should supply the following information:

- Energy Function (e.g., production)

- Energy Source (e.g., coal)

- Function Identifiers where necessary (e.g., producers, electric utilities)

- Geographic Aggregation (e.g., state, U.S. Total)

- Reported Time Interval (e.g., Ist calendar quarter, 1981)

- Units of Measure (e.g., short tons)

These are the major elements that should appear in each title. The list should be viewed as guidelines for titling as opposed to a rigid set of titling rules. (This titling syntax also applies to graphs.) 


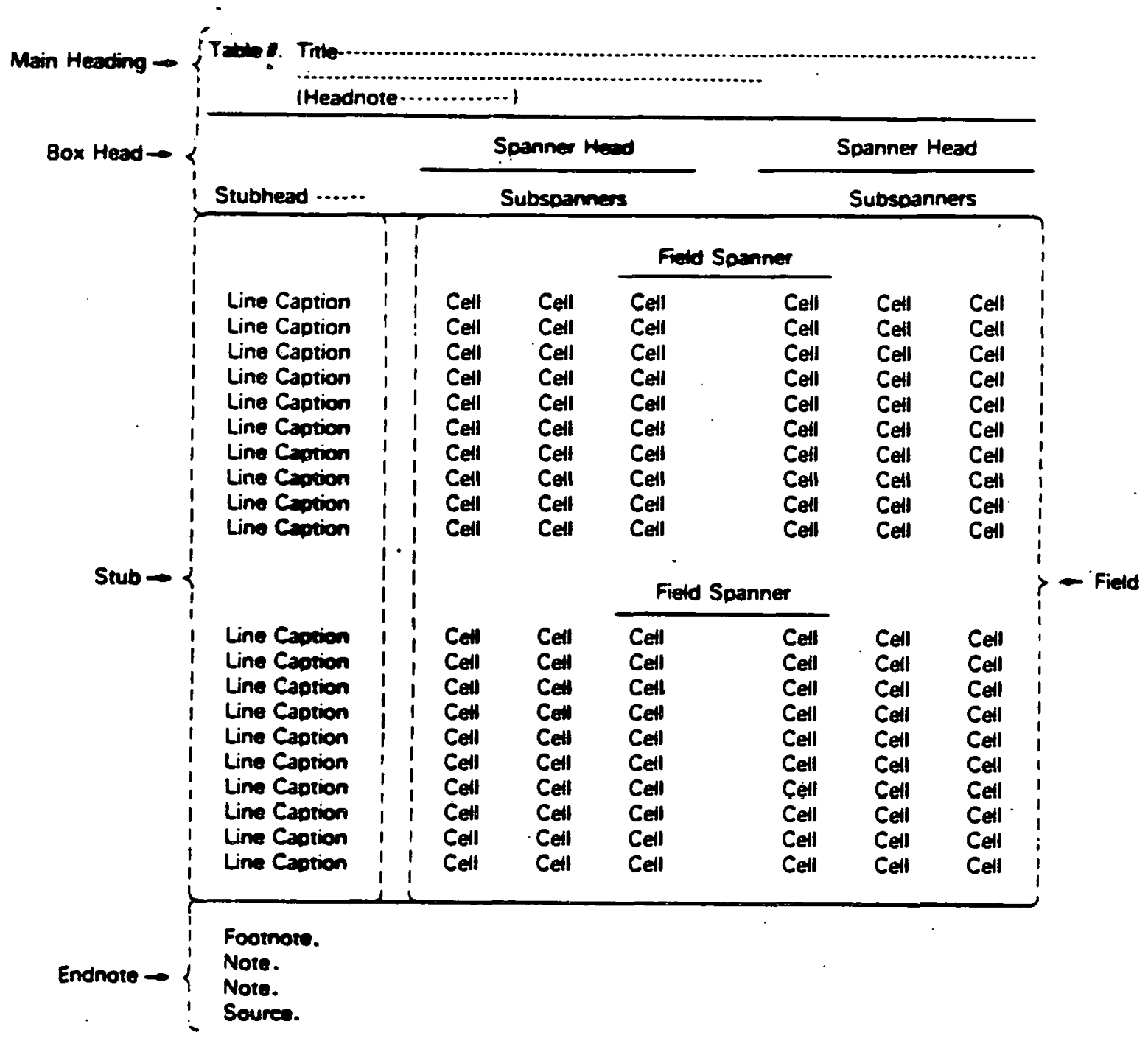

Exhibit 2. Formal Table as Shown in the EIA Publication Manual, Volume 1 
A number of options exist for the ordering of this information. To ensure consistency, one approach for ordering information within titles should be adopted for use throughout the QCR.

The initial report on the QCR contained a recommendation that all data within the publication be displayed by calendar quarter. There are two options for describing each quarter on the table:

- January - March 1981

- lst Calendar Quarter 1981

Both options identify the time period accurately. However, the first option requires less space in the title ( 20 characters versus $2 \%$ ) and in the boxhead where standard abbreviations of the months can be used (Jan-Mar). For consistency, time intervals on graphs should also read "Jan-Mar," or "J/M," if space becomes a problem.

Boxheads

The EIA and Government Printing Office (GPO) publication manuals provide clear standards for the language and layout of the stubhead, spanners and subspanners in formal tables. Confusion can occur, however, when multiple spanners and subspanners appear. The use of more than three levels of spanners should, therefore, be avoided whenever possible.

Line Captions and the Field

The line captions and the field contain the actual data within a table. Therefore, their presentation must be clear and aesthetically pleasing. 
Exhibit 3 contains a listing of type faces and sizes that may be used.

TABLES

Type face: Helvetica

Type sizes: Running heads 14B

Titles 12B

Stubs $8 B$

Body

$8 / 8 B$ (all "totals")

Endnotes

6

Lines :

$0.2 \mathrm{~mm}$

GRAPHS

Type face: Simplex

Type Size: All graph type

$8 \mathrm{~B}$

Legend

$10 \mathrm{~B}$

Endnotes

8

Exhibit 3. Suggested Type Faces and Sizes

There are two options for the placement of totals data. Each illustrative exhibit in this report presents totals data in the first column or in the first, or top, row of the table rather than the last row and right column. If used consistently throughout a publication, either option presents totals data clearly. However, the placement of totals data at the top of the table conforms to the convention of aggregate to disaggregate ordering as was discussed earlier in this report. 


\section{Endnotes}

Endnotes fulfill three functions in most publications:

- Identify sources of data

- Define unique symbols or terms

- Supply explanatory information

The EIA Publication Manual and other style manuals usually describe endnotes as consisting of up to three parts:

- Footnotes: There are two types of footnotes:

- Notes consisting of explanatory information, such as a definition or a caveat, are reterenced in the test by a letter or number $(a, 1)$.

- Short phrases or caveats ( $R=$ Revised, E=Estimate) are required frequently throughout a publication. These footnotes are referenced with a letter of symbol ( $R, E$, $(*))$.

- Notes: Explanatory information on a table or figure can be displayed in a "Note." The commnnly found notc in EIA publications is "Totals may not equal the sum of the components due to independent rounding."

- Source: The source note identifies the form or publication from which data in tables or illustrations were obtained, for example, "Source - Form EIA 6, 'Coal Distribution Report," Energy Intormation Administration, U.S. Department of Energy." The note may cuntalin two or more sources of data.

The Government Printing Office (GPO) Style Manual and the Energy Information Administration Publications Manual, Volumes 1 and 2, contain guidelines for endnote formats. The EIA publications manual states: 
"Each footnote is a self-contained unit. In each illustration or table, the first footnote begins with "a," the second with "b," and so forth. A single footnote may be keyed to several items in the same illustration.

A statement or source that recurs in a series of illustrations must be restated in full for each illustration. Do not use ibid. or other similar devices. Do not abbreviate author or title references in a footnote of an illustration or table.

The EIA Publications Manual also provides examples of endnote component ordering and language:

\section{Standard Endnotes}

apreliminary data.

${ }^{b}$ Actual production in 1977 due to the 1977-1978 United Mine Workers' Strike.

${ }^{c}$ George F. Nielsen, Keystone News Bulletin, January 1978, p.7. $\mathrm{R}=$ Revised.

Note: The decimal precision of this table is included only to specify the demand forecast and does not imply the precision of the forecast.

Source: Office of Energy Data and Interpretation, Energy Information Administration, Form EIA-9,"No. 2 Heating Oil Supply Price Monitoring Report," November 1977.

Use of Bullets in Source Note

Sources: - Bureau of Mines, U.S. Department of Interior, "Natural Gas," Minerals Yearbook, 1973-1975.

- Office of Energy Data and Interpretation, Energy Information Administration, Form EIA-9, "No. 2 Heating Oil Supply Price Monitoring Report," November 1977.

- American Association of Petroleum Geolngists, "Statistica on Exploratory Drilling in the United States," quarterly and monthly reports, 1966-1978. 
Although "self-contained" endnotes are the most efficient method of presenting reference data, full compliance with EIA format and language standards in the QCR will add many lines of detail and may diminish the readers' understanding of the data presented in the tables and graphs.

Four sections of the proposed QCR (Executive Summary, Stocks, Receipts, Consumption) will contain tables and graphs with three or more source references. Using EIA guidelines, each table and graph within these chapters should have this type of endnote:

(*) Value is less than 500 Short Tons.

Note: Totals may not equal sum of components due to independerit suunding.

Sources: Electric Utilities: Office of Energy Data Operatioñ Energy Information Administration, FPC Form 4, "Monthly Power Plant Report, : 1978-1981.

port Cóke Plants: Office of Energy Data Operations, Energy Information Administration, EIA 5, "Coke Plant Report," 1978-1981.

- Other Industrial: Office of Energy Data Operations, Energy Information Administration, EIA 3, "Quarterly Coal Consumption Report Manufacturing," 1978-1981.

- Residential/Commercial: Office of Energy Data Operations, Energy Information Administration, EIA 6, "Coal Distribution Report," 1978Iy81.

The space necessary for an endnote of this length may require that the tables within the QCR be produced in a relatively small type size or that the spacing between lines and columns be significantly reduced. Graphs may also have to be reduced. The use of tightly spaced, small type may make tables difficult to read. In addition, a lengthy footnote at the hottom of a dense table creates a page full of cluttered detail (see Exhibit 4).

'lhere are a number of options avallable that wil1. prosent the data clearly and still satisfy the intent of EIA source note guidelines.

MAXIMA's previous report on the QCR recommended that the publication include a Scope of Publication section, including: 


\section{Consumption}

Table . Consumption of Coal, U.S. Total, January - March 1981, October - December 1980, January - March 1980

(Thousand Short Tons)

Aros

January - Mareh

1981

October - December

1980

January - March

1980

U.S. Total

$x$

$x$

$x$

$\left({ }^{\circ}\right)$ Value is less than 500 Short Tons.

Note: Totals may not equal sum of components due to independent rounding.

Sources: -Office of Energy Data Operations, Energy Information Administration, FPC Form 4, "Monthly Power Plant Report," 1978 - 1981.

- Office of Energy Data Operations, Energy Information Administration, ElA 5 ytoke Plant Report," 1978 - 1981.

- Office of Energy Data Operations, Energy Information Administration, EIA 3, "Ouarterly Coal Consumption

Report - Manufacturing," 1978 - 1981.

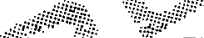

- Offlce of Energy Data Operations, Energy Information AdThinistration, ElA 6, "Coal Distribution Report," 1978 - 1981.

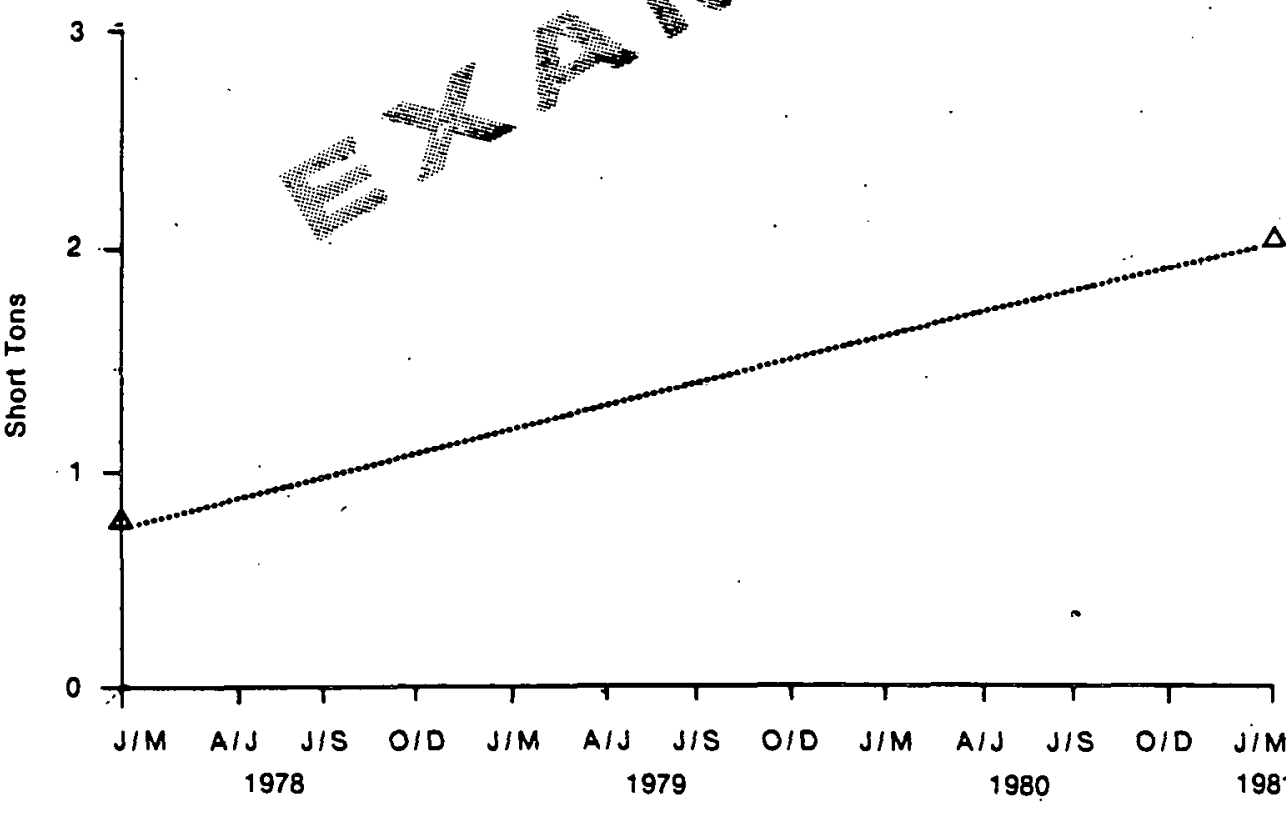

Legend

$\Delta$

10

Sources: - Offlce of Energy Data Operations, Energy Information Adminsitration, FPC Form 4, "Monthly Power Plant Report," 1978 - 1981.

- Office of Energy Data Operations, Energy Information Administration, ElA 5, "Coke Plant Report," 1978 - 1981. - Office of Energy Data Operations, Energy Information Administration, ElA 3, "Quarterly Coal Consumption Report - Manufacturing," 1978 - 1981.

-Office of Energy Data Operations, Energy Information Administration, ElA 6, "Coal Distribution Report," 1978 - 1981.

Figure . Consumption of Coal, U.S. Total by Quarter, 1978 - 1981

Exhibit 4. "Self Contained" Table and Graph 
- Data sources

- Coverage

- Reporting cycle

If this section is included, table and graph source notes can be abbreviated to a notation of the relevant form number. Readers requiring more specific data can then reference the Scope of Publication. This format is used in the Electric Power Monthly. The advantage of this alternative is the elimination of lengthy endnotes from tables and graphs. However, a comprehensive Scope of Publication will add at least one page LU LliE QCR.

A sprnnd alternative is the presentation of source notes and explanatory information in an "Explanatory Notes" page at the end of each chapter. The advantages of this format are: 1) the elimination of lengthy endnotes and 2) that sufficient room is provided to note exceptions and limitations of data in tables and graphs. 'The disadvantage is that this format may add eight pages to the QCR. 


\section{Graph Format}

The first QCR report contained a recommendation that summary graphs be included in the publication. The exhibits in this report contain examples of a format for these graphs.

There are two basic types of graphs included in OEDO publications:

- Line graphs that contain reference points in one line

- Multiple curve graphs that feature comparable reference points (months) in two or more lines (years)

The graphic exhibits in this report follow a line graph format. In the first QCR report MAXIMA recommended that all data in the QCR be displayed by quarter and that thirteen quarters be displayed in graphs. A multiple curve graph containing these data would require three lines - each consisting of only four reference points. Although multiple curve graphs are better for comparison purposes, a line graph will show trends in coal over a period of time and be more asthetically pleasing. 
THIS PAGE

\section{WAS INTENTIONALLY LEFT BLANK}




\section{Detailed Analysis of Selected Chapters}

The initial QCR report contained analyses of the data sources to be used in the QCR and general recommendations concerning the content of the publication. This section consists of a more detailed analysis of the content of some of the chapters proposed for the QCR.

\section{Executive Summary}

In the initial QCR report, we recommend that the QCR include an executive summary that would provide an overview of the publication. This can be accomplished through the use of one of three possible data presentation formats. The first and the more traditional of these formats consists of presenting summary figures from each chapter (see A in Exhibit 5). The second format provides data that can be used to quickly derive a supply and disposition balance equation (see $B$ in Exhibit 5).

However, both of these formats have limitations. A table based on a balance equation does not completely "summarize" the $\underline{Q} \underline{\text { b }}$ because it excludes data from two chapters (domestic shipments and receipts that are factored out of any balancing format) and includes a net value from another chapter (Stocks). On the other hand, a table consisting of summary data from each chapter may not clearly reflect the interrelationships of variables affecting coal supply and disposition.

A third alternative that combines both formats may resolve these problems by presenting summary information that can easily be transformed into a supply - disposition equation (see Option C in Exhibit 5). Although all three formats "sumarize" the data, the third option presents the data within the $Q \mathrm{CR}$, as well as its structure, in the clearest fashion. 
OPTION A. . SUMMARY LISTING

\begin{tabular}{|c|c|c|c|c|c|c|c|}
\hline & Producilon & Stocks & Imports & Exports & $\begin{array}{r}\text { Domestic } \\
\text { StIpments }\end{array}$ & Recelpte & Consumption \\
\hline U.S. Total & $x$ & $x$ & $x$ & $x$ & $x$ & $x$ & $x$ \\
\hline
\end{tabular}

\section{OPTION B. BALANCE EQUATION}

\begin{tabular}{|c|c|c|c|c|c|}
\hline & \multicolumn{3}{|c|}{ Sufply } & \multicolumn{2}{|c|}{ Disposition } \\
\hline & Production & $\begin{array}{c}\text { Net Stock } \\
\text { Chenge }\end{array}$ & Inpots & Exports & Consumption \\
\hline U.S. Total & $x$ & $x$ & $x$ & $x$ & . \\
\hline
\end{tabular}

OPTION C. COMBINED

\begin{tabular}{|c|c|c|c|c|c|c|c|c|c|}
\hline & \multirow[b]{2}{*}{ Production } & \multicolumn{3}{|c|}{ Stocts } & \multirow[b]{2}{*}{ Imports } & \multirow[b]{2}{*}{ Exports } & \multirow[b]{2}{*}{$\begin{array}{l}\text { Domestic } \\
\text { Shipments }\end{array}$} & \multirow[b]{2}{*}{ Recelpts } & \multirow[b]{2}{*}{ Consumption } \\
\hline & & $\begin{array}{l}\text { Beginning } \\
\text { Inventaries }\end{array}$ & $\begin{array}{c}\text { Ending } \\
\text { Inventcries }\end{array}$ & $\begin{array}{c}\text { Net } \\
\text { Chaרge }\end{array}$ & & & & & \\
\hline U.S. Total & & $x$ & $x$ & $x$ & $x$ & $x$ & $x$ & $x$ & $x$ \\
\hline
\end{tabular}


Exhibit 6 illustrates this option and Exhibit 7 displays a set of accompanying graphs that may also be included.

\section{Production}

MAXIMA's first QCR report contained the results of a limited user survey that indicated the need for coal production data by state. In the past, state production data have been included in the Weekly Coal Production

Report. However, these data will be eliminated sometime this year, according to EIA sources.

Although problems exist with obtaining comprehensive accurate state-level data, the usefulness of the QCR will be improved if a method of obtaining these data can be developed and state production data included.

\section{Domestic Shipments}

MAXIMA's previous report included a recommendation that some coal shipment data be included in a "distribution" chapter. The term "Distribution" indicates a number of activities from shipment to marketing. The term "domestic shipments" is more precise, hence, the title for this chapter. The domestic shipments chapter of the $\mathrm{OCR}$ has three requirements. The data presented should include:

- Amount of coal shipped by coal producers

- Geographic linkage between the producer and consumer

- Method of transportation

In theory, all three requirements could be satisfied in one table: domestic shipments of coal by producing districts, state of destination, consumer category and method of transportation. However, this table will require forty pages of tightly-spaced data, which when combined with summary tables will substantially increase the size of the QCR. In addition, it is questionable whether the majority of the potential readers of the QCR will require or be able to use data at this level of detail. 


\section{Executive Summary}

Table 1. Supply and Disposition of Coal by Quarter, January-March 1978 January-March 1981

(MIllion Short Tons)

Year and

Stocks

Quarter

Beginning Ending Not Domestic
Inventories Inventories Change Imports Shipments Recolpts Exports Consumption

1978 Total

January - March

April - June

July - Eeptember

October - December

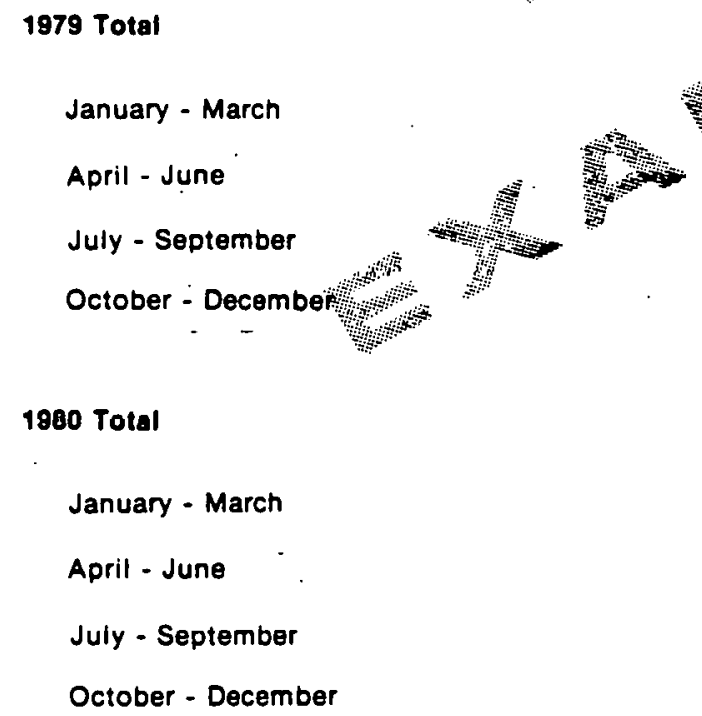

1979 Total

January - March

April - June

July - September

Note: Totals may not equal sum of components due to independent rounding.

Sources: •FPC Form 4, EIA 3, EIA 6, EIA 5, IM 145, EM 522, FPC Form 423, State Agencies.

Exhiblt 6. Executive Summary Table 


\section{Executive Summary}

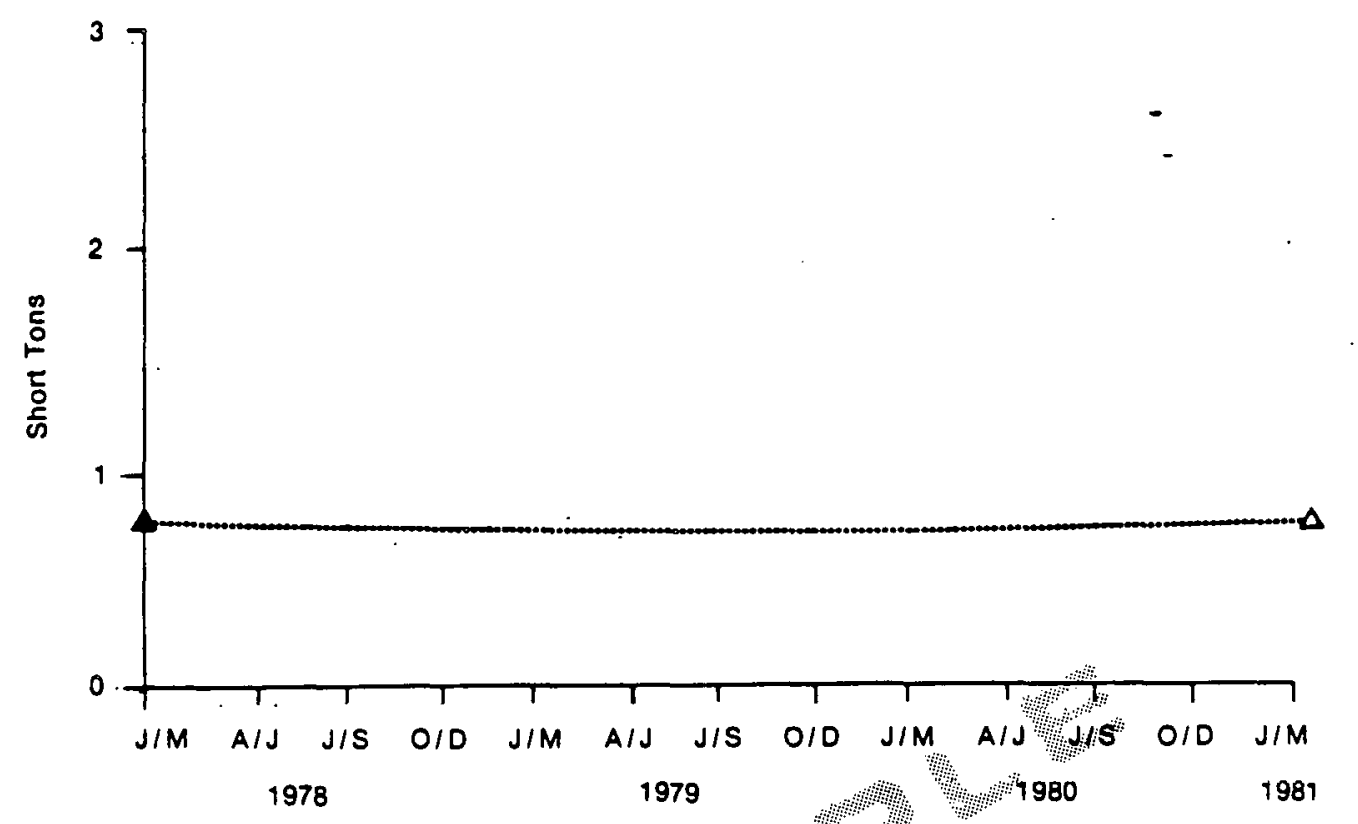

Legend

$\Delta$

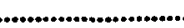

Sources: -EIA 6, State Agencies, AM 455.

Figure . Supply of Coal by Quarters 19781981

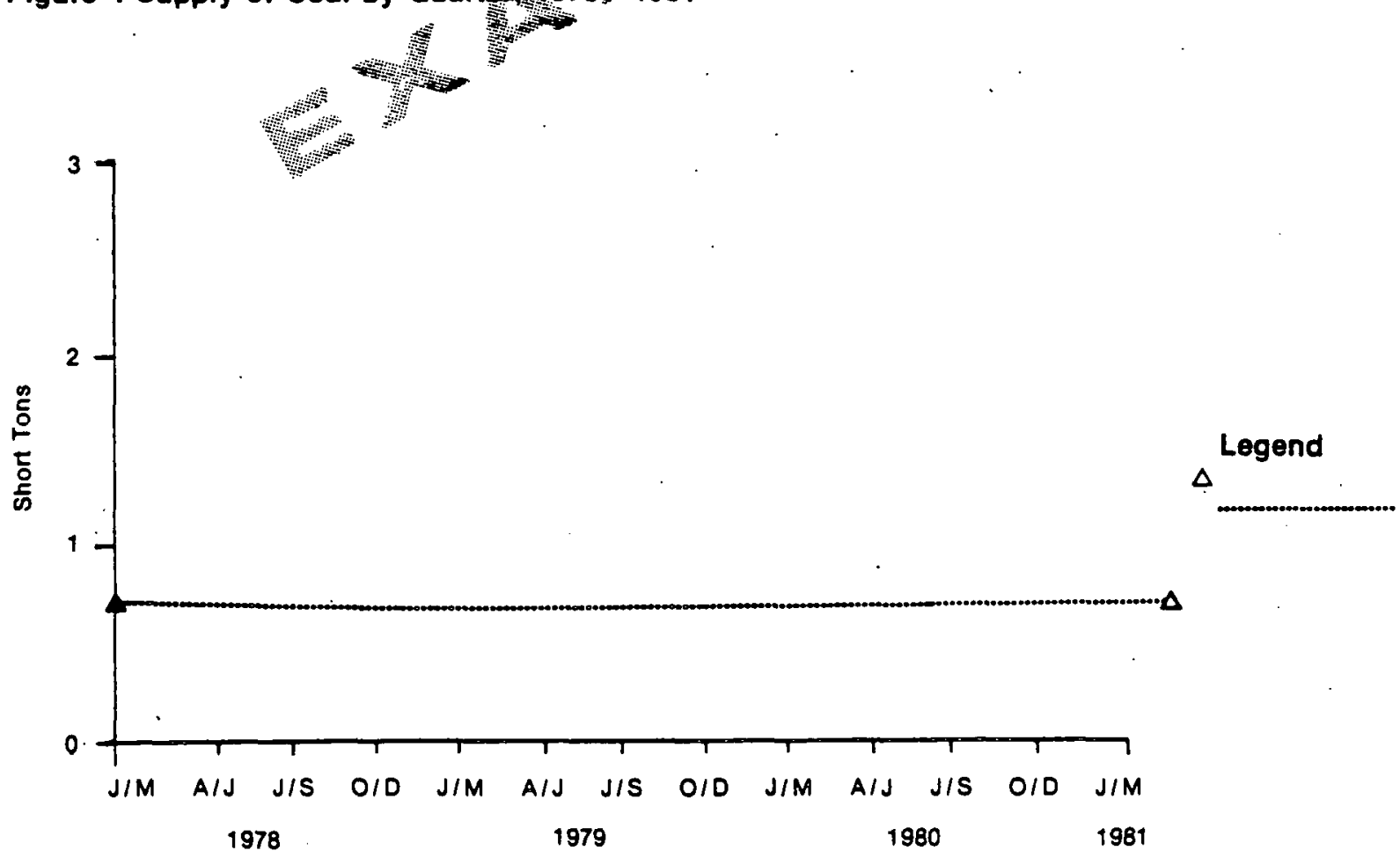

Sources: •FPC Firm 4, EIA 3, EIA 6, EIA 5, EM 522.

Figure . Disposition of Coal by Quarter, 1978 - 1981

\section{Exhibit 7. Supply and Disposition Graphs}


We have researched alternative data presentation formats in an attempt to find one that will both satisfy the requirements of the domestic shipments chapter and display the data economically and clearly. These attempts fall into two general categories: consolidated tables and a series of tables. The data display options under each of these categories are discussed in the following paragraphs.

\section{Consolidated Tables}

\section{Option 1}

As stated previously, although a consolidated table containing geographic linkage, consumer category and transportation data is the simplest solution to presenting domestic shipments data, it is not economical. The lengthy table required by the cross-referencing of four variables (coal producing districts, states, consumer categories and method of transportation) is not appropriate for a summary publication. If one of these functions were eliminated, the size of the table could be substantially reduced.

The receipts chapter of the proposed QCR follows the domestic shipments chapter and contains coal receipts data by state and consumer category. Therefore, consumer category data could be excluded from the domestic shipments section without significantly reducing the scope of the data. If required, the reader could review shipments and transportation data in the domestic shipments section and trace the flow of coal within each state in the receipts section.

There are two possible formats for the display of origin to destination and transportation data. These are shown in Exhibits 8 and 9 . The use of either option reduces the number of pages required from about forty to somewhere between ten and fifteen.

Consolidated domestic shipments tables displaying data for three or four functions and their disaggregations will, to a large extent, consist of zero values. One format for a domestic shipment table places the 24 coal 


\section{Domestic Shipments}

Table . Domestic Shipments of Coal by Method of Transportation, State of Destination and Producing District, January - March 1981

(Thousand Short Tons)

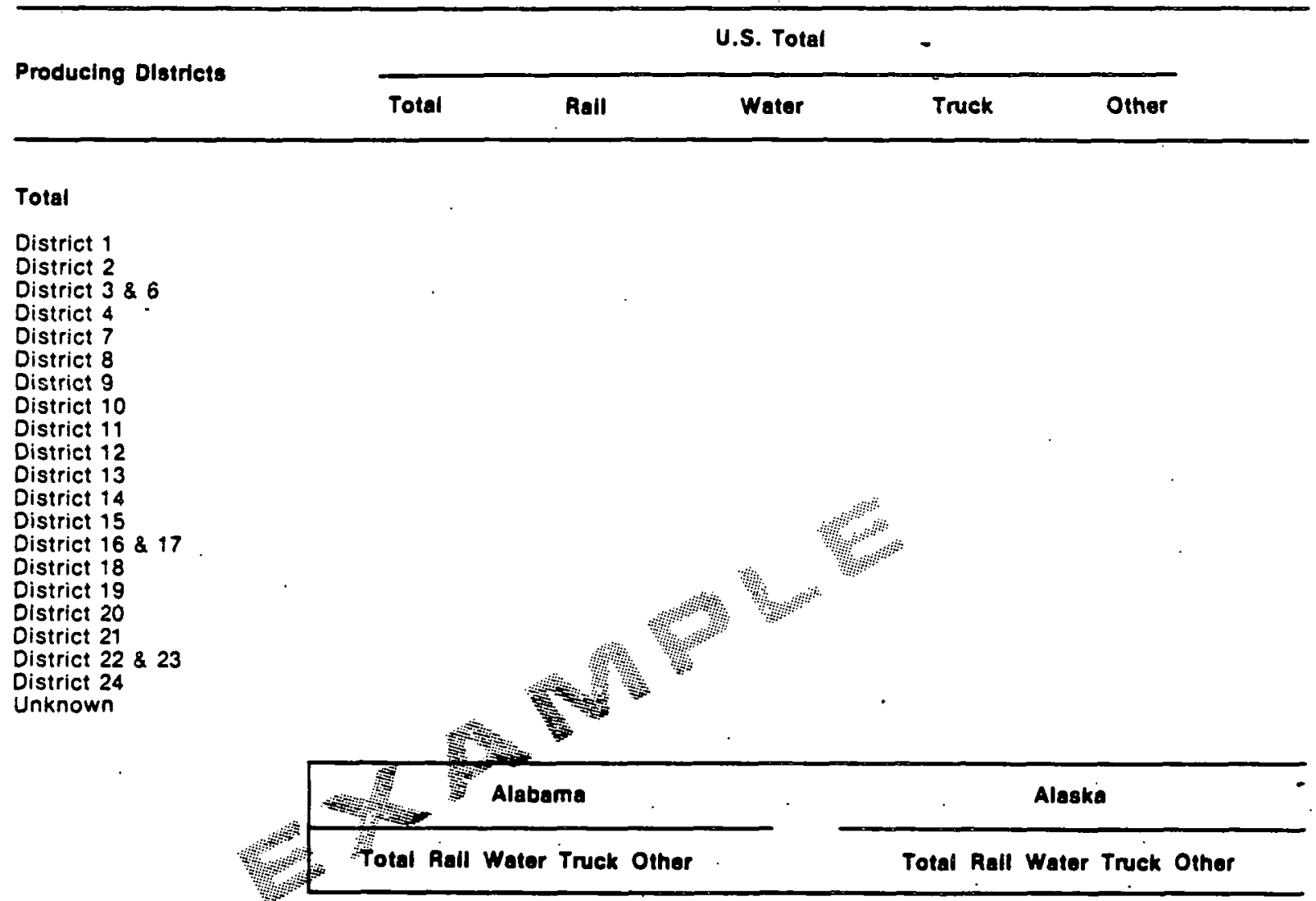

Total

District 1

District 2

District $3 \& 6$

District 4

District 7

District 8

District 9

District 10

District 11

District 12

District13

District 14

District 15

District $16 \& 17$

District 18

District 19

District 20

District 21

District 22 \& 23

District 24

Unknown

(") Value is less than 500 Short Tons

Note: Total may not equal sum of components due to independent rounding.

Source: •EIA 6.

Exhibit 8. Domestic Shipments Table Format 


\section{Domestic Shipments}

Table . Domestic Shipments of Coal by Producing District, State of Destination and Method of Transportation, January - March 1981

(Thousand Short Tons)

\begin{tabular}{llllllllllll}
\hline & \multicolumn{1}{c}{ Coal Producing District } \\
\cline { 2 - 9 } $\begin{array}{l}\text { State } \\
\text { Mothod of Transportation }\end{array}$ & Total & $1-23$ & 1 & 2 & 386 & 4 & 7 & 8 & 8 & 10. & 11 \\
\hline
\end{tabular}

U.S. Total

Rail

Water

Truck

Other

$$
\begin{aligned}
& \text { Alabama } \\
& \text { Total } \\
& \text { Rail } \\
& \text { Watpr } \\
& \text { Truck } \\
& \text { Other } \\
& \\
& \text { Alaska } \\
& \text { Total } \\
& \text { Rail } \\
& \text { Water } \\
& \text { Truck }
\end{aligned}
$$

Other

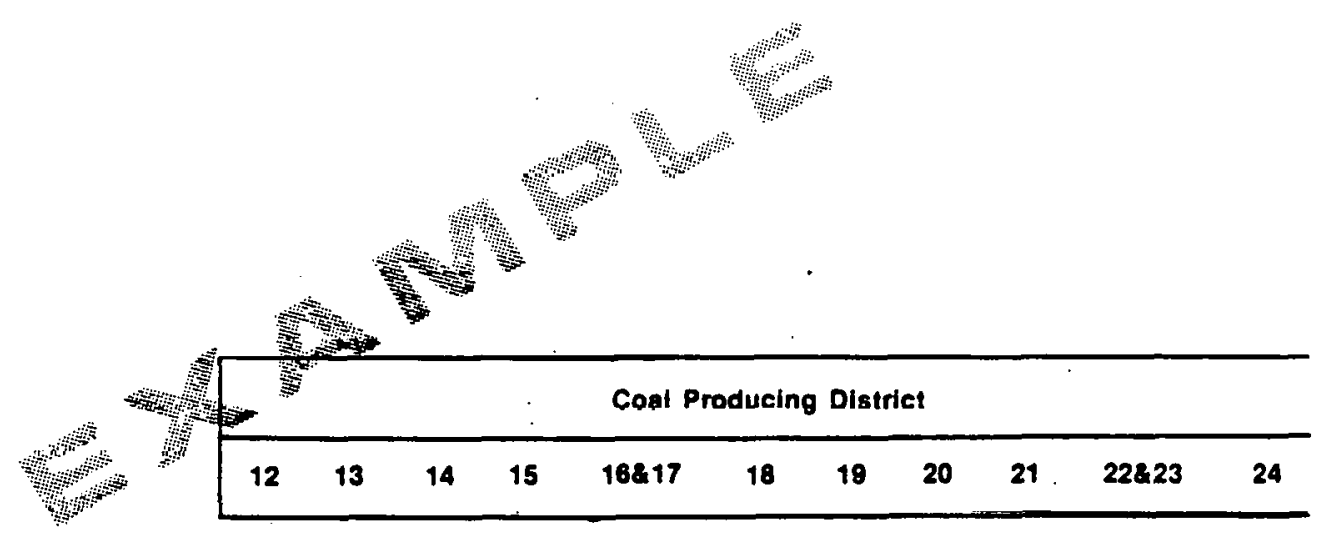

U.S, Total

Rail

Waler

Truck

Other

Alabama

Tolal

Rail

Water

Truck

Other

Alaska

Total

Rail

Water

Truck

Other

(*) Value is less than 500 Short Tons.

Source: -EIA 6.

Exhibit 9. Alternative Domestic Shipments Table Format 
producing districts in the table spanner and the state and transporation data in the line captions. If a state receives a quantity of coal from one of the 24. producing districts by each of the four methods of transportation, line captions for all four methods and a total will have to be present on the table. This requires a display of 120 data cells, of which only five will contain values greater than zero.

\section{Series of Tables}

A partial solution to the problem of inefficient data display can be achieved by presenting domestic shipments data in a series of tables rather than just one. The use of this method reduces the number of data functions or disaggregations displayed on each table in a series.

\section{Option 2}

We have reviewed alternative displays based on published coal data (see Appendix A). It is possible to reduce the size of a three function table (origin, destination and transportation) by limiting the number of disaggregations displayed on each table. Under this option, the 24 coal producing districts are divided into eastern coal producing districts (Nos. 1-11, 13 and 24) and western coal producing districts (Nos. 12, 14-23) using the Mississippi River as a common boundary (see Exhibit 10).

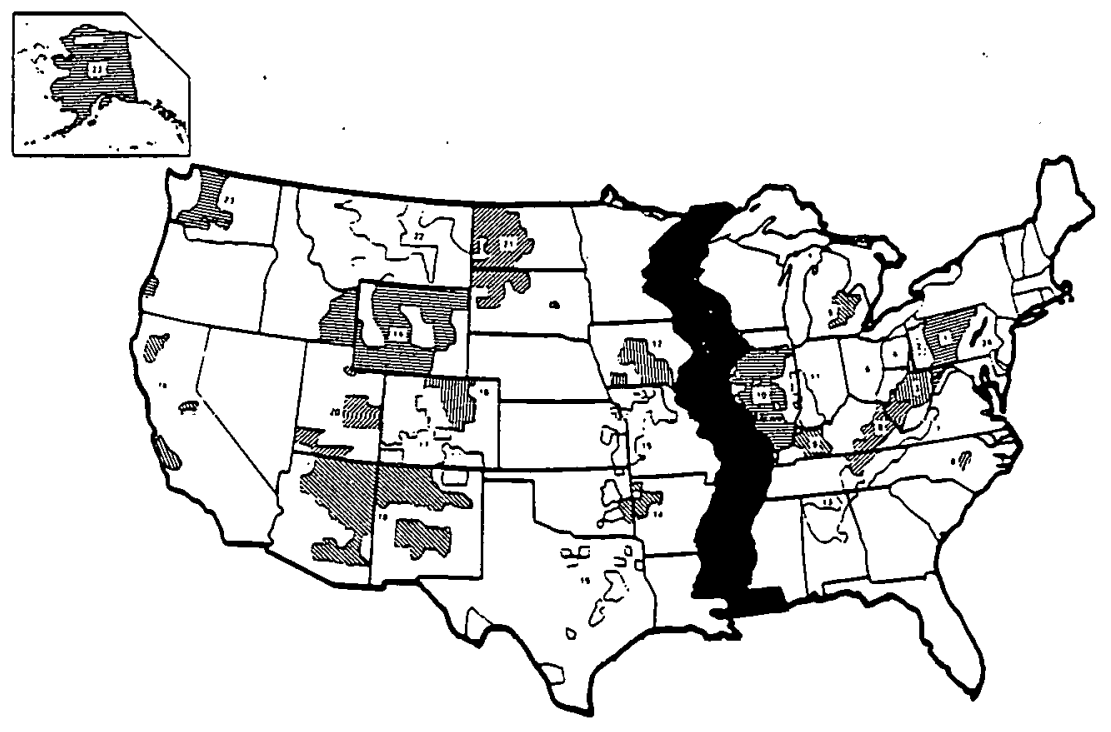

Exhibit 10. Coal Producing Districts 
The four methods of transportation are displayed in separate tables. States which do not receive coal by one or more methods of transportation, (e.g., rail, water) are excluded from those tables. Consumer categories are not included.

There are eight tables in this series. These are:

- Domestic Shipments of Coal by Rail from Eastern Producers to State of Destination

- Domestic Shipments of Coal hy Rail from Western Producers to State of Destination

- Domest1c Shipments of Coal by Water from Eastern Producers to State of Destination

- Domestic Shipments of Coal by Water from Western Producers to State of Destination

- Domestic Shipments of Coal by Truck from Eastern Producers to State of Destination

- Domestic Shipments of Coal by Truck from Western Producers to State of Destination

- Domestic Shipments of Coal by Other Methods from Eastern Producers to State of Destination

- Domestic Shipments of Coal by Other Methods from Western Producers to State of Destination

Within this series of tables, the number of line captions required on each table is reduced from 51 (the 50 states and D.C.) to a maximum of 44 (eastern producer rail shipments), and a minimum of 10 (eastern other shipments), with an average of around 26 line captions.

If each table displays up to twelve columns of data, this series will require about six pages. However, based on the data in the Coal Distribution Quarterly (Jan-Mar 1980) none of these tables contain less than eighty percent zero values.

There are other alternative formats that further 1imit the disaggregations on each table. For example, the states could be divided into eastern and western regions, but 47 out of 50 receive coal and very little space would be 
saved. Another alternative format is to divide both the producing districts and the states into separate regions. However, use of this option, as well as others that further limit the number of disaggregations presented in a table, require greater numbers of tables that may scatter the data and make comprehensive understanding or use increasingly difficult.

\section{Option 3}

The two previous options have consisted of alternative formats for the display of geographic linkage data (origin to destination) and transporation data. The major difficulties in the use of these options are caused by the attempt to simultaneously display transportation or other data with the 24 coal producing districts and the states. The third option consists of a series of tables that are not centered around geographic origin to destination data. This series is:

- Domestic Shipments of Coal by Producing District

- Domestic Shipments of Coal by State of Destination

- Domestic Shipments of Coal by Producing District and State of Destination

- Domestic Shipments of Coal by State of Destination and Method of Transportation

- Domestic Shipments of Coal by Consumer Category and State of Destination (see Exhibits 11, 12, 13, 14, and 15)

This series of tables presents four types of data: These are:

- The amounts and origin of coal shipments

- The state of destination of the shipments

- By what method of transportation the states receive coal

- Consumer category

These five tables satisfy the requirements for the domestic shipments section. In addition to these five tables, summary tables and graphs for each of the four functions should also be included in the chapter. 


\section{Domestic Shipments}

Table . Domestic Shipments of Coal by Producing District, January - March 1981, October - December 1980, January - March 1980

(Thousand Short Tons)

\begin{tabular}{lcccc} 
& & & \\
Producing & January - March & October-December & January - December & 1980 \\
District & 1981 & 1980 & 1980 \\
& & & 1981 \\
\hline
\end{tabular}

U.S. Total

District 1

District 2

Diotriot 3

District 4

District 7

Distriet 8

Diotriot 0

District 10

District 11

District 12

District 13

District 14

District 15

District $16 \& 17$

Distrlet 18

District 19

District 20

District 21

District $22 \& 23$

District 24

Unknown

(') Value is less than 500 Shor Tons.

Note: Totals may not equal sum of components due to independent rounding.

Cource: eIA 0. 


\section{Domestic Shipments}

Table . Domestic Shipments of Coal by State of Destination, January - March 1981, October - December 1980, January - March 1980

(Thousand Short Tons)

State

January - March 1981
October.- December 1880
January - March 1980

Year to Date

\section{U.S. Total}

Alabama

Alaska

Arizona

Arkansas

California

Colorado

Connecticut

Delaware

District of

Columbia

Florida

Georgia

Hawaii

idaho

IIIinois

Indiana

lowa

Kansas

Kentucky

Louisiana

Maine

Maryland

Massachusetts

Michigan

Minnesota

Mississippi

Missouri

Montana

Nebraska

Nevada

New Hampshire

New Jersey

New Mexico

New York

North Carolina

North Dakota

Onio

Oklahoma

Oregon

Pennsylvania

Rhode Island

South Carolina

South Dakota

Tennessee

Texas

Utah

Vermont

Viroinia

Washington

West Virginia

Wisconsin

Wyoming

(") Value is less than 500 Short Tons.

Source: -EIA 6.

Exhibit 12. Domestlc Shipments Table - Shipments by State of Destination 


\section{Domestic Shipments}

Table. Domestic Shipments of Coal by Producing District and State of Destination, January - March 1981

(Thousand Short Tons)

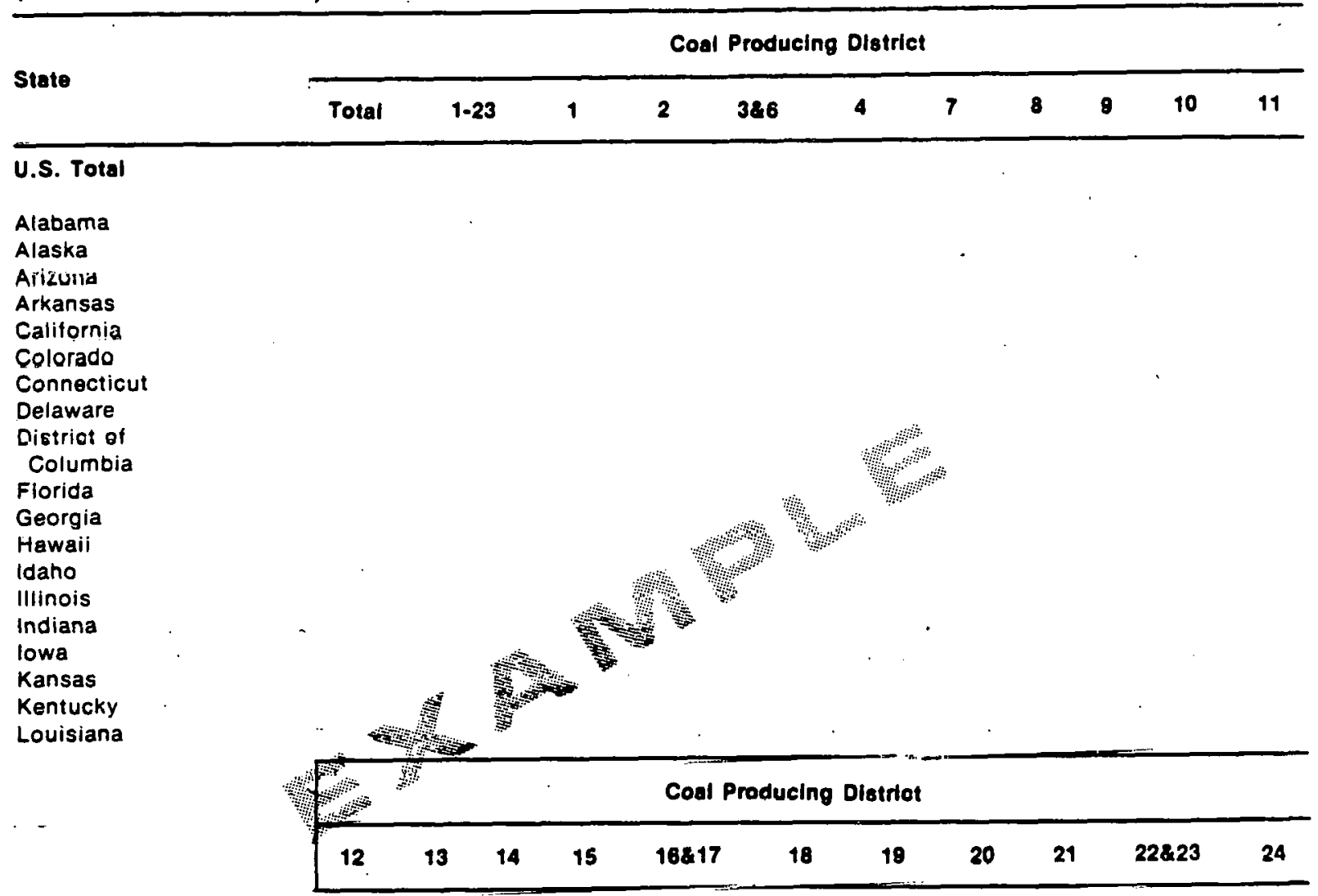

11. S. Total

Alabama
Alaska
Arizona
Arkansas
California
Colorado
Connecticut
Delaware
District of
Columbia
Florida
Ceoroin
Hawaii
Idaho
Illinois
Indiana
lowa
Kansas
Kentucky
Louisiana

(') Value is less than 500 Short Tons.

Source: •EIA 6.

Exhibit 13. Domestic Shipments Table - Origin/Destination 


\section{Domestic Shipments}

Table . Domestic Shipments of Coal by Method of Transportation and State of Destination, January - March 1981

\section{(Thousand Short Tons)}

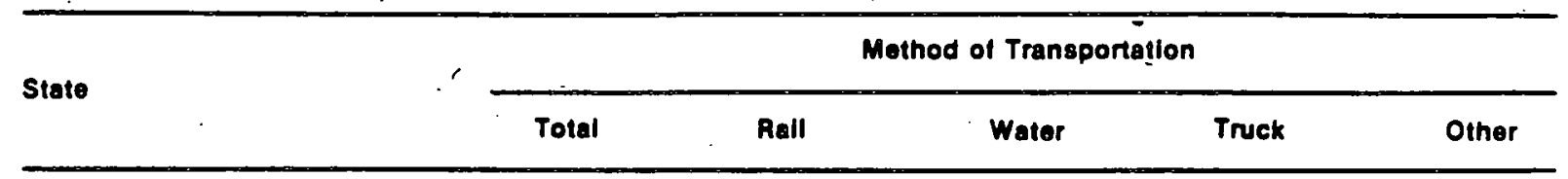

U.S. Total

Alabama

Alaska

Arizona

Arkansas

California

Colorado

Connecticut

Delaware

District of

Columbia

Florida

Georgia

Hawaii

Idaho

Illinois

Indiana

lowa

Kansas

Kentucky

Lousiana

Maine

Maryland

Massachusetts

Michigan

Minnesota

Mississippi

Missouri

Montana

Nebraska

Nevada

New Hampshire

New Jersey

New Mexico

New York

North Carolina

North Dakota

Ohio

Oklahoma

Oregon

Pennsylvania

Rhode Island

South Carolina

South Dakota

Tennessee

Texas

Utah

Vermont

Virginia

Washington

West Virginia

Wisconsin

Wyoming

(') Value is less than $\mathbf{5 0 0}$ Short Tons.

Source: -EIA 6.

Exhibit 14. Domestic Shipments Table - Transportation 


\section{Domestic Shipments}

Table . Domestic Shipments of Coal by Consumer Category and State of

Destination, January - March 1981

(Thousand Short Tons)

1

Consumer Categōry

State

\begin{tabular}{ccccc}
\hline Total & $\begin{array}{c}\text { Electric } \\
\text { Utillties }\end{array}$ & $\begin{array}{c}\text { Coke } \\
\text { Plants }\end{array}$ & $\begin{array}{c}\text { Other } \\
\text { Industrial }\end{array}$ & $\begin{array}{c}\text { Residential/ } \\
\text { Commerlcal }\end{array}$ \\
\hline
\end{tabular}

U.S. Total

Alabama

Alacka

Arizona

Arkansas

Californio

Colorado

Connecticut

Delaware

District of

Columbia

Florida

Georgia

Hawaii

Idaho

Kansas

Kentucky

Louisiana

Maine

Maryland

Massachusetts

Michigan .

Minnesota

Mississippi

Missouri

Montana

Nebraska

Nevada

New Hampshire

New Jersey

New Mexico

New York

North Carolina

North Dakota

Onio

Oklahoma

Oregon

Pennsylvania

Rhode Island

Juuth Caivilita

South Dakota

Tonnessee

Texas

Utah

Vermont

Virginia

Washington

West Virginia

Wisconsin

Wyoming

(") Value is less than 500 Short Tons.

Source: -EIA 6.

Exhibit 15. Domestic Shipments Table - Consumer Categories/Destination 
Summary

Of the three options previously discussed, the third seems most appropriate for a summary publication such as the QCR. The most important data are presented in a concise format that is both economical and clear.

Due to the format of these tables some tables can display data for only one period, for example, October - December. If historical data are required, each table with current data can be presented with an additional year to date table.

\section{Receipts}

The first QCR report contained a recommendation to include the quantity and value of coal receipts at consumers. The data are available in detail from the three major coal consumers (electric utilities, coke plants and manufacturers). Sulfur and ash content, coal rank and cost data are reported by electric utilities. Coal rank and cost data are also available from coke plants and manufacturer.

Extensive electric utility coal cost and quality data are published in the Cost and Quality of Fuels for Electric Power Plants Monthly. No cost data are published on the other consuming sectors on a monthly or quarterly basis.

OEDO collects comprehensive data on three factors affecting coal price:

- Type of Purchase

- Type of Mine

- Coal Rank

The QCR, as a summary coal publication, should contain some or all of this pricing data. This can be accomplished by displaying rank, purchase and mining data for each of the three consumer categories. 


\section{THIS PAGE}

WAS INTENTIONALLY

LEFT BLANK 


\section{Appendix A. \\ Analysis of Domestic Shipments Data}

Our analysis of Domestic Shipments presentation formats included a review of coal shipments; destination and transportation data. The review was an attempt to discern patterns in any of these activities which might be helpful in organizing domestic shipments data. Exhibits 16, 17, 18, 19 and 20 are selected examples of our results.

All data found on the grids are based on those found in the Coal-Distribution Quarterly。 Blanks equal zero values in Exhibits 17 through 20. 


\begin{tabular}{|c|c|c|c|c|c|c|c|}
\hline $\begin{array}{l}\text { Destination } \\
\text { Census Region \& State }\end{array}$ & $\begin{array}{l}\text { Total } \\
\text { Districts }\end{array}$ & $\begin{array}{l}\text { From } \\
\text { Eastern } \\
\text { Producers } \\
\text { (Districts } \\
1-13824 \text { ) }\end{array}$ & $\begin{array}{l}\text { From } \\
\text { Western } \\
\text { Producers } \\
\text { (Districts } \\
\text { 14-23) }\end{array}$ & $\begin{array}{l}\text { Destination } \\
\text { Census Region \& State }\end{array}$ & $\begin{array}{l}\text { Total } \\
\text { Districts }\end{array}$ & $\begin{array}{l}\text { From } \\
\text { Eastern } \\
\text { Producers } \\
\text { (Districts } \\
1-13824 \text { ) } \\
\end{array}$ & $\begin{array}{l}\text { From } \\
\text { Western } \\
\text { Producers } \\
\text { (Districts } \\
\text { 14-23) }\end{array}$ \\
\hline $\begin{array}{l}\text { Eastern States } \\
\text { New England } \\
\text { Connecticut } \\
\text { Main } \\
\text { Massachusetts } \\
\text { New Hampshire } \\
\text { Rhode Island } \\
\text { Vermont } \\
\text { Middle Atlantic } \\
\text { New Jersey } \\
\text { New York } \\
\text { Pennsylvania } \\
\text { East North Central } \\
\text { Illinois } \\
\text { Indiana } \\
\text { Michigan } \\
\text { South Atlantic } \\
\text { Delaware } \\
\text { D.C. } \\
\text { Florida } \\
\text { Georgia } \\
\text { Maryland } \\
\text { North Carolina } \\
\text { South Carolina } \\
\text { Virginia } \\
\text { West Virginia } \\
\text { East South Central } \\
\text { Alabama } \\
\text { Kentucky } \\
\text { Mississippi } \\
\text { Tennessee }\end{array}$ & $\begin{array}{r}3 \\
4 \\
6 \\
3 \\
4 \\
1 \\
\\
6 \\
8 \\
8 \\
15 \\
13 \\
13 \\
14 \\
4 \\
4 \\
5 \\
5 \\
7 \\
6 \\
3 \\
2 \\
6 \\
8 \\
13 \\
11 \\
9 \\
i 0\end{array}$ & $\begin{array}{r}3 \\
4 \\
6 \\
3 \\
4 \\
1 \\
\\
6 \\
8 \\
8 \\
10 \\
9 \\
10 \\
\\
4 \\
5 \\
5 \\
7 \\
6 \\
3 \\
2 \\
6 \\
8 \\
9 \\
9 \\
10 \\
6 \\
10\end{array}$ & $\begin{array}{l}0 \\
0 \\
0 \\
0 \\
0 \\
0 \\
\\
0 \\
0 \\
0 \\
\\
5 \\
4 \\
4 \\
\\
0 \\
0 \\
0 \\
0 \\
0 \\
0 \\
0 \\
0 \\
0 \\
\\
4 \\
1 \\
3 \\
0\end{array}$ & $\begin{array}{l}\text { Western States } \\
\text { West North Central } \\
\text { Iowa } \\
\text { Kansas } \\
\text { Minnesota } \\
\text { Missouri } \\
\text { Nebraska } \\
\text { North Dakota } \\
\text { South Dakota } \\
\text { West South Central } \\
\text { Arkansas } \\
\text { Louisiana } \\
\text { Oklahoma } \\
\text { Texas } \\
\text { Mountain } \\
\text { Arizona } \\
\text { Colorada } \\
\text { Idaho } \\
\text { Montana } \\
\text { Nevada } \\
\text { New Mexico } \\
\text { Utah } \\
\text { Wyoming } \\
\text { Pacific } \\
\text { California } \\
\text { Oregon } \\
\text { Washington. }\end{array}$ & $\begin{array}{r}13 \\
7 \\
13 \\
11 \\
6 \\
5 \\
3 \\
\\
6 \\
5 \\
5 \\
13\end{array}$ & $\begin{array}{l}0 \\
1 \\
1 \\
1 \\
0 \\
1 \\
2 \\
1\end{array}$ & $\begin{array}{l}7 \\
4 \\
5 \\
5 \\
5 \\
2 \\
2 \\
\\
3 \\
2 \\
4 \\
8 .\end{array}$ \\
\hline
\end{tabular}


Exhibit 17. Domestic Shipments of Coal by Rail

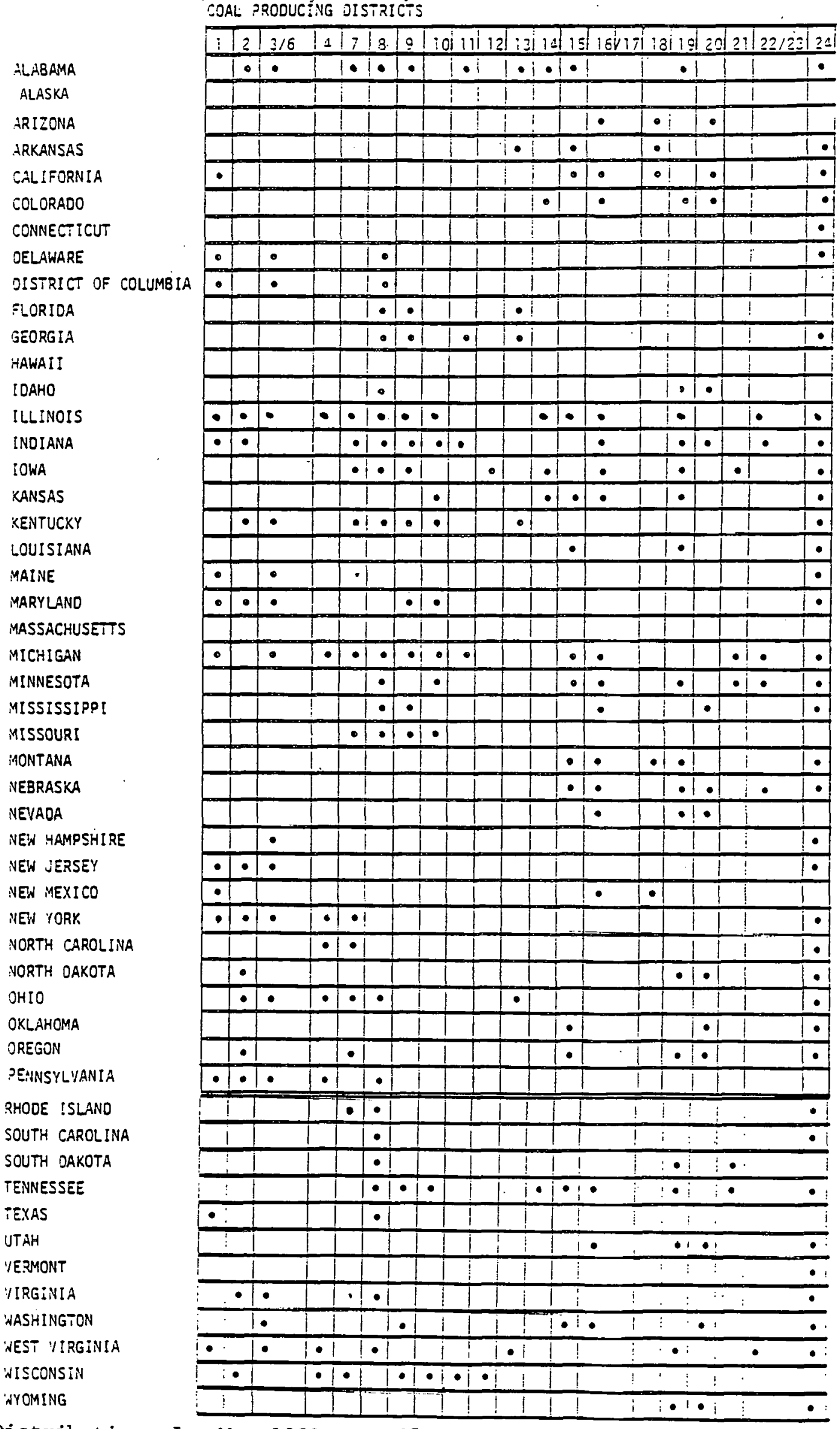


Exhibit 18. Domestic Shipments of Coal by Water

COAL POODUC:NG JISTRIC:S

\begin{tabular}{|c|c|c|c|c|c|c|c|c|c|c|c|c|c|c|c|c|c|}
\hline IL.:BAMA & & $\div$ & & 1 & & - $1 \cdot$ & - & $!$ & & $\cdot i$ & $\cdot 1$ & & & & 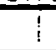 & & \\
\hline ALASKA & & & & $i$ & 1 & & & i & 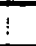 & 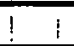 & 1 & & f & & 1 & & \\
\hline TRIZOMA & & & & $!$ & $i$ & & & 1 & 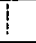 & $i$ & 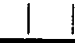 & & & 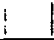 & $\vdots$ & & $!$ \\
\hline ARKANSAS & & & & $!$ & 1 & & & $i$ & 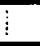 & : & 1 & & & 1 & $\overline{1}$ & & $\ldots$ \\
\hline CAL:FORNIA & & & & 1 & 1 & & $T$ & 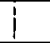 & $\vdots$ & $i$ & I & & & & 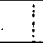 & & I \\
\hline COLORADO & & & & 1 & $!$ & & 1 & $i$ & i & $1:$ & & & $:$ & & ! & & \\
\hline CONNECTICUT & $\because$ & & & & $!$ & & 1 & & $!$ & $1 \vdots$ & 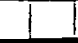 & 1 & E & & $\vdots$ & & -1 \\
\hline JELLWHARE & & & & & 1 & & & I & i & $\vdots$ & & & $i$ & I & $i$ & & 1 \\
\hline JISTRIC, DF COLUMBIA & & & & & $!$ & & 1 & I & & 1 & 1 & & $\vdots 1$ & 1 & 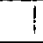 & & 1 \\
\hline FLORIDA & & & & & $i$ & - & - & $1 \cdot 1$ & & $|\cdot|$ & 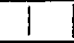 & & 1 & & ! & & ! \\
\hline GEORGIA & & & & & -1 & $\cdot 1$. & $1 \cdot$ & 1 & & 1 & & & 11 & 1 & $i$ & & 1 \\
\hline HAWALI & & & & & 1 & & 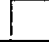 & T & T & 1 & 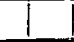 & & $!$ & & $\vdots$ & & 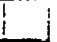 \\
\hline IDAHO & & & & & 1 & & 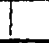 & 11 & I & I & 1 & 1 & $i$ & & $!$ & & \\
\hline ILLINOIS & & & & - & 1 & -1. & - & I. & & $\cdot$ & $\cdot 1 \cdot 1$ & - & 1 & $\cdot 1$ & $i$ & & 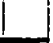 \\
\hline INDIANA & & & -2 & - & & - & $1 \cdot$ & L & & & & & 1 & & 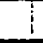 & & \\
\hline IOWA & & & & & 1. & - $1 \cdot$ & $\therefore$ & & & & & & $I$ & & 1 & & \\
\hline KANSAS & & & & & 1 & 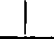 & 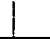 & & & i & & & $i$ & & 1 & & \\
\hline KENTUCXY & & & - & 10 & 1 & - $1 \cdot$ & - & & & 1 & 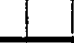 & 1 & 1 & & 1 & & \\
\hline LOUISIANA & & & & & 1 & 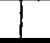 & - & 1. & & & $\cdot$ & 1 & 1 & & $!$ & & \\
\hline MAINE & & & & & i & • & 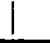 & & & 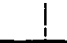 & $\cdot 1$ & I & $\cdot 1$ & & $!$ & & - \\
\hline MARYLAND & .10 & $\cdot$ & & - & 1 & & $i$ & & & 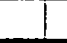 & 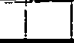 & 1 & 1 & & $\mathrm{i}$ & & \\
\hline MASSACHUSETTS & - & - & & & se 100 & - & 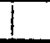 & & & 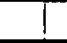 & & 1 & 11 & & 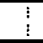 & & \\
\hline MICHIGAN & $\cdot \cdot$ & - & Io & - & & & - & & & & & 1 & $!$ & & & - & \\
\hline MINNESOTA & - & $\bullet$ & te & . & & - & $\bullet$ & & & & 1 & & 1 & & 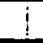 & & \\
\hline MISSISSIPP! & & & & & 1 & - & - & $\cdot 1$ & & - & & 1 & 11 & 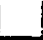 & 1 & & I \\
\hline Lssount & & & & & 1 & $\therefore$ & $1 \cdot 0$ & - & & & $\cdot 1 \cdot 1$ & 1 & 11 & & 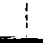 & & \\
\hline iAONTANA & & & & & i & & & & & & 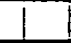 & 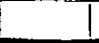 & 11 & 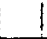 & 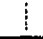 & & \\
\hline NEBRASKA & & & & & 1 & & 1 & & $i$ & & & I & $i$ & 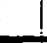 & $\vdots$ & & \\
\hline NEVYADA & & & & & 1 & & 1 & & & & & I & I & & $i$ & & I \\
\hline NEW HAMPQHTDE & & & & & 1 & & I & & & & & 1 & 1 & & $!$ & & \\
\hline NEN JERSEY & $\cdot$ & - & & & 1 & & 1 & & & & & I & 1 & I & $!$ & & \\
\hline NEN MEXICO & & & & & $i$ & & 1 & & & & & 1 & 1 & 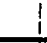 & 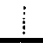 & & \\
\hline NEN YORK & $-1 \cdot$ & & & & 1. & & I & & & & & I & ! & & $!$ & & $1 \cdot$ \\
\hline NURTH CAROLINA & & & & & 1 & 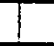 & I & & & & & 1 & 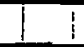 & & $i$ & & \\
\hline NORTH OAKOTA & & & & & - & & 1 & & & & | & 1 & & 11 & i & & i \\
\hline OHIO & $\cdot$ & - & 1. & $\dot{-}$ & ! & $1 \cdot$ & 1 & - & & 1 & 1 & I & -1 & & $i$ & & 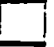 \\
\hline OKLLAHOMA & & & & & 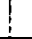 & & $i$ & 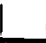 & 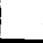 & & & 1 & $i$ & $i$ & 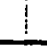 & & 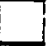 \\
\hline OREGON & & & & & & & $i$ & 1 & & it & 1 & i & & 1 & $i$ & & \\
\hline PE!INSYLVIANIA & & & & 1. & & 1 & 1 & I & & 1 & $i$ & 1 & ! & 1 & 1 & & \\
\hline RHOOE ISLANO & $!$ & & & & & & $!$ & & & 1 & 1 & $!$ & i & $i$ & & & \\
\hline SOUTH CAROLINA & $i$ & & & & & 1 & 1 & I & i & 1 & 1 & I & $\vdots \quad 1$ & $\vdots$ & & & \\
\hline SOUTH OAKOTA & & & & & & $!$ & L & I & & 1 & 1 & 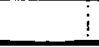 & $\vdots$ & 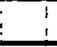 & & & \\
\hline TENNESSEE & - : & - & se & & & • & - & 1. & & 1 & 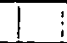 & & 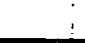 & $\vdots$ & & & \\
\hline TEXAS & & & & - & & 1 & & $!$ & I & 1 & - & $\vdots$ & $!$ & 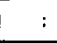 & & & \\
\hline TAH & 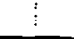 & & & 1 & & $!$ & I & | & i & $!$ & 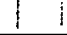 & $:$ & - & & & & \\
\hline IE:TMONT & & & & & & i & & I & 1 & $!$ & . & & $i$ & & & & \\
\hline IIRGINIA & & & & - & & 1 & & i & & 1 & $1:$ & 1 & & & & & \\
\hline ASHINGTON & - & $\cdot$ & - & $1 \cdot$ & & 1 & $!$ & i & 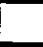 & $!$ & 1 & & & & & & - \\
\hline 'NEST YIRGINIA & & & & 1 & & 1 & 1 & i & & 1 & $i$ & & & & & & \\
\hline ISCONSIN & 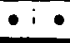 & & & ! & & $! \cdot$ & $1 \cdot$ & i & & -! & 1 & $\mathrm{i}$ & & & & & \\
\hline YOMING & $!$ & & & 1 & & 1 & 1 & ! & 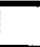 & $!$ & $T$ & $\bar{\vdots}$ & $!$ & & & & \\
\hline
\end{tabular}


Exhibit 19. Domestic Shipments of Coal by Truck

GOAL PRODUC:NG DISTRICTS

ILABAMA

ALASKA

ARIZONA

ARKANSAS

CALIFORNIA

COLORADO

CONNEGTICUT

OELAWARE

DISTRICT OF COLUMBIA

FLORIDA

GEORG IA

HAWAII

IOAHO

ILLINOIS

INDIANA

IOWA

KANSAS

KENTUCKY

LOUISIANA

MAINE

MARYLANO

MASSACHUSETTS

MICHIGAN

MINNESOTA

MISSISSIPPI

MISSOURI

MONTANA

VEBRASKA

NEVADA

NEW HAMPSHIRE

NEW JERSEY

YEW MEXICO

NEW YORK

NORTH CAROLINA

YORTH OAKOTA

OHIO

OKLAHOMA

DREGON

WEIINSTLIANLA

RHODE ISLANO

SOUTH CAROLINA

SOUTH DAKOTA

TENNESSEE

TEXAS

UTAH

IERMONT

VIRGINIA

WASHINGTON

NEST VIRGINIA

NISCONSIH

NYOMING

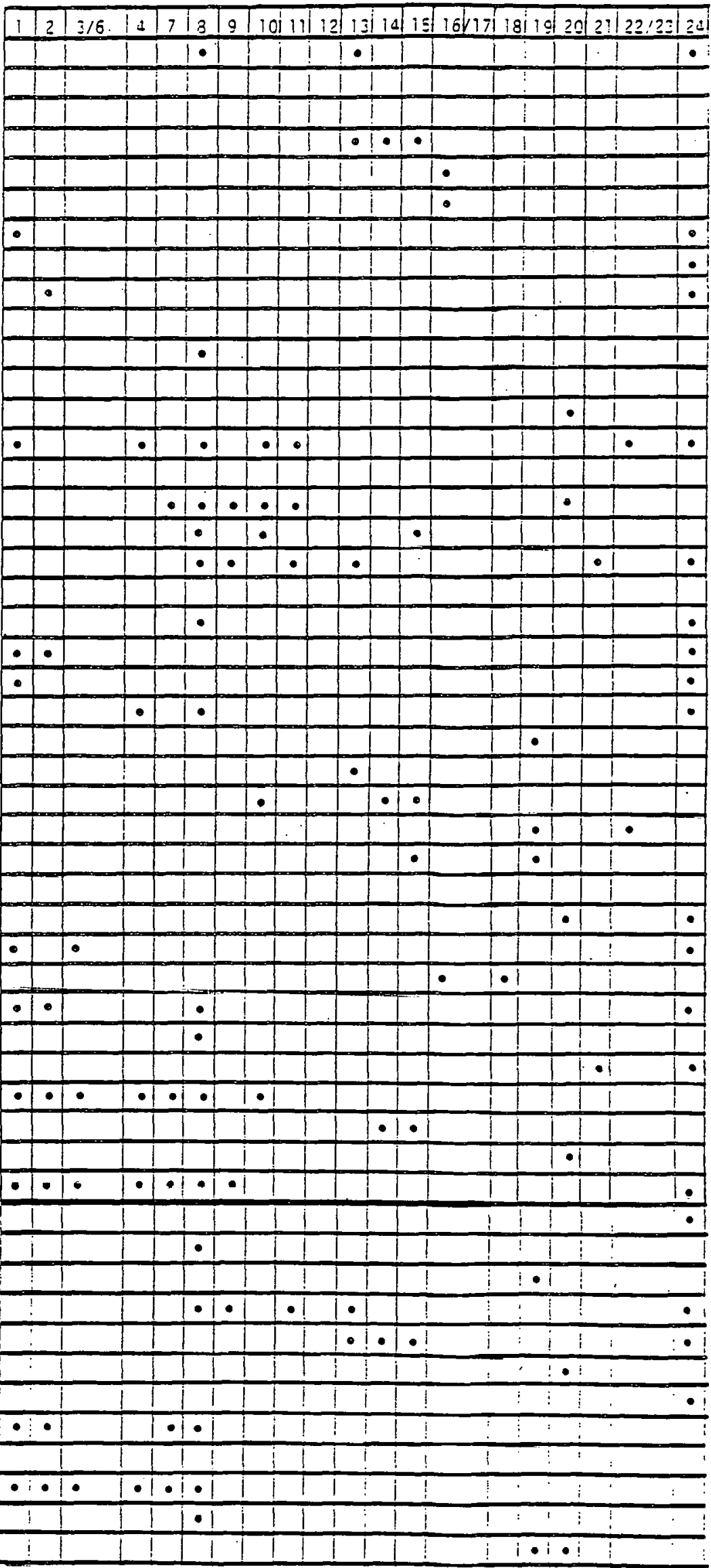


Exhibit 20. Domestic Shipments of Coal by Other Methods of Transportation COAL PRODUC:NG JISTRICIS

ILABAAYA

ALASKA .

ARIZONA

ARKANSAS

CALIFORNIA

COLORADO

CONNECTICUT

DELAWARE

DISTRICT OF COLUMBIA

FLORIDA

GEORGIA

HAWAII

I DAHO

ILLINOIS

INOIANA

IOWA

KANSAS

KENTUCKY

LOUISIANA

MAINE

MARYLANO

MASSACHUSETTS

MICHIGAN

MINNESOTA

MISSISSIPPI

MISSOURI

MONTANA

NEBRASKA

WEVAOA

NEW HAMPSHIRE

NEW JERSEY

NEN MEXICO

NEW YORK

HORTH CAROLINA

YORTH DAKOTA

$\mathrm{OH}$ IO

OKLAHOMA

OREGON

PEINSYLVANIA

RHOUE ISLANO

SOUTH CAROLINA

SOUTH DAKOTA

TENNESSEE

iE.XAS

UTAH

YERMONT

IIRGINIA

WASHINGTON

NEST IIRGIHIA

NTSCONSIN

AYOMING

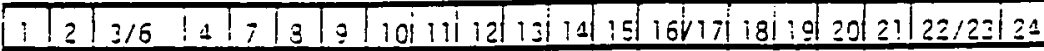

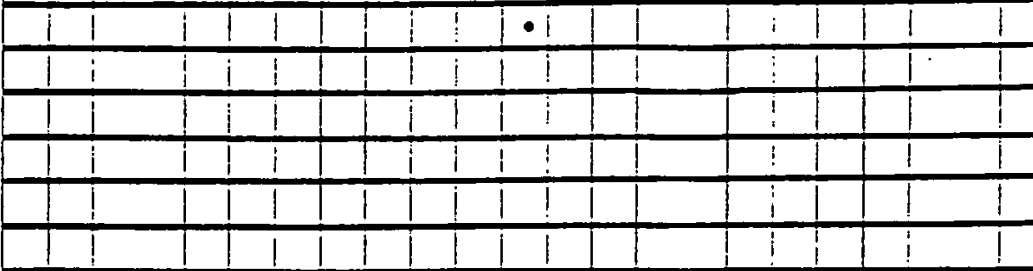

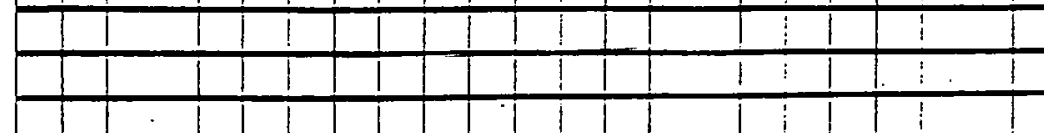

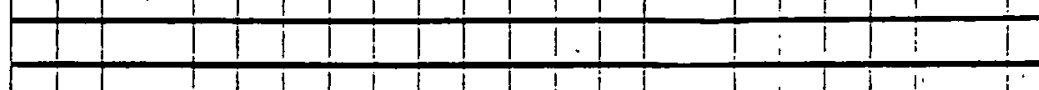

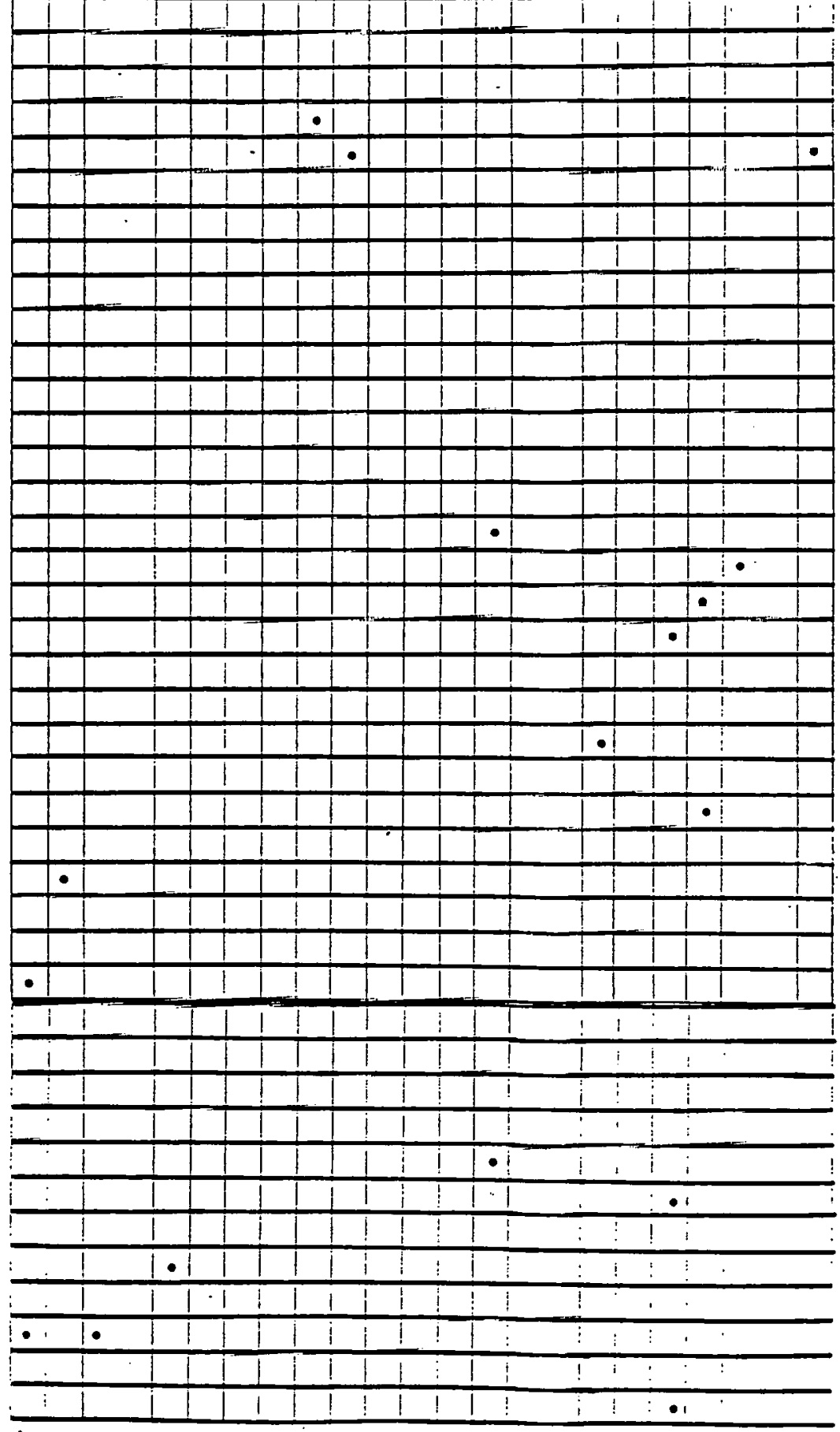

